\title{
The Murder of Maurice Cathala (1958). Autopsy of Apolitical Murder at the dawn of the Fifth French Republic
}

\author{
Bryan Muller \\ Doctorant en Histoire au laboratoire CRULH, Équipe d'accueil n`3945 \\ Doctorant contractuel chargé d'enseignement à l'UFR SHS de Metz (Université de Lorraine) \\ Représentant doctorant au pôle scientifique TELL (Temps, Écritures, Lettres, Langues) et à l'École \\ Doctorale Humanités Nouvelles
}

While the Fourth Republic is tormented by a series of crises, the war in Algeria provokes unprecedentedupheavals. The conscripts were summoned in April 1957, the police showed up in the streets the following year and asked for the return of General de Gaulle. On the $13^{\text {th }}$ May 1958, the army rebelled in Algerand formed the Committee of Public Safety. The Committeecalled for the formation of a government headed by General de Gaulle. Some were terrified, the others were excited: the political parties then reacted and entered into conflicts. There were ongoing street fights and attacks. Lucien Neuwirth, a fervent gaullist, described the situation:

After the RPF was put to sleep, we created the Social Republicans. Some ofthe members were political personalities like Michel Debré, Edmond Michelet or Roger Frey. Also young people as Guy Ribeaud. And especially someone who was going to play a crucial role afterwards, Léon Delbecque. The Social Republicans had everything of a small group, but in the end, this structure allowed us to survive. It was necessary to survive because as the tragic developments of the Algerian affair progressed, we felt that there, everything was going to explode. [...] Algeria was a boiler [...]. The Fourth Republic was incapable of solving the important problems, and especially the colonial drama. Everything suggested that the nation was about tocollapse. De Gaulle was the onlypersonality able to preventing this[Translated from French by Bryan Muller of Lucien Neuwirth's interview with RémiKauffer, published in Le Figaro Magazine on the $5^{\text {th }}$ April 1998].

On the path to collapse, the regimehad no choice than to hand the power over to the General de Gaulle. On June $1^{\text {st }}$, the latter was elected President of the Council of the Fourth Republic: the last one under this republic. As a matter of fact, one of his first actions was to propose a new Constitution through a referendum. Officially launched on the $6^{\text {th }}$ September 1958, the campaign for the referendum was the theater of an explosion of militant violence. The fights, death threats, attacks and other conflicts between the people in favor of the referendum and those against it, have been increasing since May $13^{\text {th }}$ and reached the peak of violence in September. Toulouse area was not an exception and the city of Toulouse had been witnessing daily battles for three months. It was in this context of extreme tension that a young gaullist activist, Maurice Cathala, was murdered by communist militants while he wasplacing posters in favor of the referendum. In this article,after having described the political evolution of the Fourth Republic, I will focus on the chain of events and their direct consequences on the local political situation, and move onto the reasons that led to the murder - the only one of the 1958 referendum campaign.

\section{The Chain of Events}

\section{Contested institutions}

The Fourth Republic suffers first of all from a major handicap: its creation was made in a difficult context which from the outset did not unite public opinion around this new Republic. Between the abolition of the Third Republic in October 1945 and the adoption of the Fourth Republic, a full year passed. The first constitution proposed by the Constituent Assembly was rejected by the French, influenced partly by the positions of De Gaulle who condemned the parliamentary regime in Bayeux's speech. The Constitution was finally adopted by referendum on $13^{\text {th }}$ October 1946 in a tense climate linked to budgetary difficulties and the tensions of decolonisation: as a result of fatigue, only two thirds of the French turned out to vote. The Fourth Republic was therefore born of the approval of only $1 / 3$ of the French people.Moreover, these institutions, which are struggling to emerge, do not take into account the mistakes of the past. The fear of personal power, a trauma due to the excesses of the Vichy regime, made the constituents forget the difficulties of the Third Republic. The National Assembly is the centre of power: permanently gathered, it gives birth and death to governments. The President of the Republic enjoys significant powers: he is the head of the French Union and appoints the President of the Council. But in practice, the Presidents of the Fourth Republic will only play a secondary role. 
The principle of the double investiture of the President of the Council, combined with the abuse of the question of trust, makes this function a more than uncertain one.

\section{Chronic ministerial instability}

The potential risks contained in the institutions quickly became a reality. The Fourth Republic regains the instability of the Third. 23 governments will succeed each other in 12 years. Moreover, the intrinsic difficulties of the Fourth Republic are aggravated by the national context.First, it must bear the brunt of the opposition of two powerful parties that emerged from the Second World War haloed.

The PCF (Parti Communiste Français), on the one hand, which started out as one of the "75,000 shot", has a significant parliamentary weight. The dismissal of the communist ministers by Ramadier in May 1947 only increased the tension with the regime. On the other hand, the RPF (Rassemblement du Peuple Français), created by de Gaulle in April 1947, even if it does not have sufficient parliamentary weight to paralyse the National Assembly, active propaganda against the regime, in particular by promoting the benefits of a presidential regime. Despite everything, the Fourth Republic resists thanks to the constitution of the "Third Force": to keep the majority, socialists and Christian democrats must seek on the right (moderate, radical) the support lost on the left with the PCF.

However, divided on the school question (Barangé law on aid to free schools of 1951), the "Third Force" dissolved to give way to growing ministerial instability. From this unstability, only two personalities stand out, those of Pinay and Pierre Mendès-France. Pinay first (with his centre-right government) marked the Fourth Republic in 1952 with the success of his financial policy, which made it possible to overcome inflation. Pierre Mendès-France then, Radical (center-left party in France, very influential under the Third Republic), remains in the memories for his effective settlement of the Indochinese question with the Geneva Agreements signed in 1954 and the problems of Tunisia and Morocco. Caught off guard on the Algerian question, trust was denied in 1955. Apart from these two personalities, the French political life of the Fourth Republic is all the more dull as the French are completely disinterested in it. Disappointed by the return of politicians from the Third Republic (such as Ramadier, Herriot or Queuille), tired of a too complex parliamentary game, never consulted on major problems (such as decolonisation), public opinion quickly broke away from the regime. Even more serious, anti-parliamentarianism is reborn and developing rapidly - Poujadism, a movement of craftsmen and small traders that is gradually becoming politicized by limiting itself to the far right, is the most telling example.

\section{Colonial wars, major factors of the regime's fall}

The responsibility of the Fourth Republic in the colonial rout of France must be put into perspective. First of all, because it was difficult for it given the political context to do better: moreover, the Fifth Republic, in domestic conditions that were more favourable to it, lost just as many territories and in equally disastrous circumstances.Moreover, if we can blame the Fourth Republic for having fought the war, we must not forget that public opinion as a whole and almost all political staff refuses to "sell off the empire" and will remain attached to it for a long time. In addition, the Cold War context reinforced France's duty to its colonies to prevent them from communist danger, particularly in Indochina.

Finally, Algeria is a very delicate issue for France given the very strong links with this settlement colony, which has one million Europeans out of 10 million Algerians and has been linked to France for more than 120 years. Despite these mitigating circumstances, it must be admitted that the Fourth Republic has not been able to define a clear and coherent colonial policy, most often remaining very wait-and-see as symbolized by the immobility of the Radical Queuille government. In 1954, when no government wanted to take the risk of taking firm positions on the Indochinese question, it was not until the providential arrival of MFPs that both solved this thorny problem and that of Tunisia, to which it had granted internal autonomy. The Fourth Republic knows neither how to win the wars of decolonization nor how to impose peace through negotiation: it died of this impotence.

The fall finally occurred because of the "Algerian events", the height of the French decolonization problems. The conflict began in 1954. In 1956, Guy Mollet was still looking for a "pacification, election, negotiation" solution, while the FLN demanded immediate independence and the moderates at the beginning of the conflict, who, like Ferhat Abbas,were only claiming a little more autonomy, and were now in a crushing minority given the virulence of the repression that had fallen on the country. After the fall of Mollet, the situation became worse with a succession of ministerial crises. When Pflimlin was finally invested in May 1958, after a month of vacancy in power, it was already too late. On May 13, a riot broke out in Algiers, a Public Salvation Committee was created, chaired by General Massu. Judging the country on the brink of civil war, President René Coty called de Gaulle, the only one capable, according to him, of making the army obey. On June $1^{\text {st }}, 1958$, he was invested and granted the right to revise the Constitution. 
The referendum campaign that followed in September 1958 marked the end of the Fourth Republic. It is in this context that the assassination of Maurice Cathala took place.

\section{The Chain of Events}

\section{A night battle}

$26^{\text {th }}$ September 1958. It was two o'clock in the morning when communist militants, who were going to the party headquarters (street Pargaminières) after a meeting at the Palais des Sports, learned that Gaullists were placing posters around the universities of law and letters. Three vehicles with a dozen men immediately went to the scene. Louis Richon, 37 years old, responsible of the Communist Security Service, took four individuals to his black Frégate and took another road. All of them had truncheons, molotovs cocktails, iron bars and guns.

Arriving quickly at the scene, the first three vehicles droped men who attacked the Gaullist militants "without being provoked".Albert Lautmann Street, thirty activists of theConvention Républicainewere puttingposterscalling to support General de Gaulle and vote "yes" to the referendum. Officially unarmed, witnesses reported that there had been an exchange of shots, suggesting that somegaullists were armed with firearms. However, the vast majority of them were not expecting to be attacked, given the number of militants present, and they were powerlessunder armed and determined enemies. The fights were tough. A dozen gaullists, when they saw the weapons, did not take the fight and ran to the square of the Capitol whilescreaming "the Cossacks are coming! ". The others were quickly overwhelmed by the situation. The Communists threw molotovs cocktails on the vehicles of their opponents between two blows of truncheons.

Maurice Cathala, younger brother of the future Deputy René Cathala, tried to preserve his parents' car, a Juvaquatre, by parking it on place Anatole France. The goal was to return to the fight after thatto help the militants who were still struggling with the PCF. While he was manoeuvring his van he met the Frégate driven by Richon, a hundred meters away. Richon, coming from Delville Street, immediately fired Cathala's car. According to the police ballistic unit, at least two other passengers were reported to have fired and one of them even came out of the vehicle to approach the young man before shooting. In the end, Maurice Cathala diedfrom his injurieson the way to the hospital. He had four bullets in his body including one which cut his lung. At the same time the gaullist survivors took their injured and ran away. The Communists, when they heard about the murder, freaked out and ran away as well. It was a clutter: the Communists instinctively returned to the PCF's headquarters while the Gaullists were fleeing in all directions.

Thanks to the surprise effect and the equipment used, the Communists had no casualties. On the Gaullist side, however, several were wounded by the strokes of truncheons and iron bars, and the young Cathala succumbed to his wounds. The police tried to clear up the case and apprehended nine militants. Five said they had participated in the "AlbertLautmann street fight" but denied any involvement in the murder. They accused the passengers of the vehicle of shooting the young man. According to the Chamber of Accusation, the passengers of the vehicle could be Claverie, Maurin, Lendrin and Cammas. But because of the lack of evidence and the multiple contradictions in the testimonies provided by the suspects, the Court decided to release them. However, Louis Richon was sentenced to death on the $2^{\text {nd }}$ February 1961. On the run, Richon managed to use the clandestine networks of his party to reach Prague through Italy. His family was under surveillance but managed to use the same networks a few years later to settle with him in Prague anyway. Officially this former resistant and military career, described as "a good family father", is the murderer of Maurice Cathala. Contemporary Communists are far from adhering to this hypothesis. If one of them is guilty, it would not be the person in charge of the Security Service. Richon would have neverbeen in possession of a $11 \mathrm{~mm}$, caliber of the bullet that caused the death, but a $9 \mathrm{~mm}$. At Pargaminières Street, people thought that the real culprit was likely a former judo teacher who later became a criminal. He lived in Saint-Michel, possessed a caliber 11,47 and was present in the "Frégate". Richon would have covered him under a feeling of guilt or duty (a leader must cover his men).

\section{Maurice Cathala, new banner of anticommunism?}

Whether Louis Richon wasthetrue murderer or not, he remained the true culprit in the eyes of the population. The PCF, already little appreciated and considered by a part of the Toulouse people as a traitor, because of its support to the Algerian independentists, lost all credibility. As the investigation was going, the population held its breath and rejected "the Soviets". They followed closely the progress of the investigation. The "Frégate" of Louis Richon was found on the $30^{\text {th }}$ September at dawn in Camarade, near Mas-d'Azil (Ariège). The fugitive was not spotted, which made the police believed that he was hidding in Andorra.

The named Jean Richon is still actively sought after. According to some information, he would be in Andorra. [...] It should be recalled [...] that six communists militants, who have acknowledged their participation in the fight between poster collectors on the night of $25^{\text {th }}$ to $26^{\text {th }}$ September, are currently 
held at the Detention House in Toulouse. [...] According to some information, it would not be impossible for him [Richon] to hide in Andorra. This information has not been verified by the Judicial Police yet. In this respect, it should be recalled that Mr Robert Barran, former rugby captain of the Toulouse stadium and former journalist of the sports section in the newspaper " Le Patriote ", a communist municipal councilor from Toulouse, currently living in Paris, was Andorra vigorier for a few months, after liberation.The police is currently looking for the owner of a fourth car that reportedly participated in the brawl between poster collectors on the night of the murder.

In fact, Richon never even went to Ariège. He found refuge at a militant's housein Haute-Garonne and waited until the investigators oriented their research towards Spain to go in Italy.

The police dividedits troops to find the fourth vehicle, which they were not certain existed at the time - they will be certain when the discovery will be made. The investigation was struggling to progress and Toulouse wasin effervescence. Ahuge crowd attended Maurice Cathala's funeral at the Saint-Sernin Basilica, in the presence of Jacques Foccart and Léon Delbecque (important gaullist figures of the time). The press insisted at length on the emotion that ran through the city. Anti-Communism exploded at this moment. The Communist Party received numerous letters of threat in its headquarters. In the gaullist press as inthe anti-gaullist, people could read a lot of attacks against Communists. In Le Figaro, an editorialist wrote that "the red mask has fallen. We know now where the killers, the thugs, the nervis are. We know where the fascists are. Their color is also known. They are red. Like the blood they have on their hands". AGET payed tribute during his funeral to the "bravery" of the young man, while his newspaper Toulouse Université dedicated its first page to the death of Maurice Cathala.

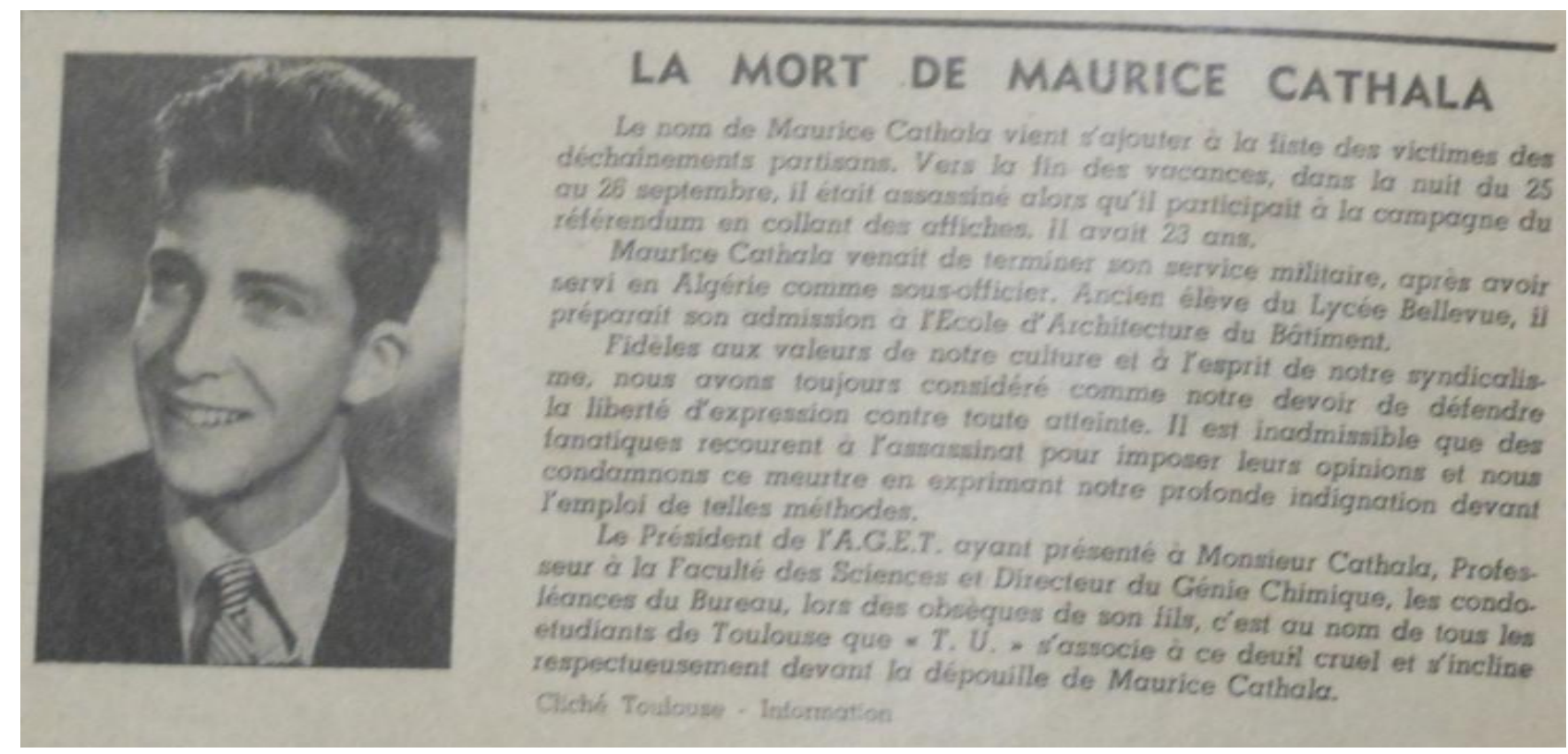

The death of Maurice Cathala (Toulouse Université, No. 25, November 1958)

Everywhere in the city all the gaullist sympathizers and the undecided rallied to General de Gaulle. Anti-Communism played a big role in it, but it is undeniable that the death of Maurice Cathala served as a trigger. Jacques Godfrain explained that he rallied and led his "little campaign" in his high school by drawing in the classrooms the cross of Lorraine after the events of the $13^{\text {th }}$ May. He described the strong resentment of the population towards the PCF followingthe drama. The Communists were unable to set up a system of defense that could calm the public opinion. They tried to justify the murder clumsily,explaining that it was not really a brawl between poster collectors but "a political brawl wherewe can regret that it has made a victim" orchestrated by "fascists". The deputy of Haute-Garonne, Jean Llante, had spoken of "settlement account between fascist organizations". A "leak" from the police quickly changed the Communist argument: the murder was premeditated. The pro-gaullist posters were publicly threatened with many death threats, and one of the Frégate's passengers took time to circle the vehicle to execute the victim. From now on, wisdom told to the Communist leaders to avoid carefully the fight of $26^{\text {th }}$ September in a discussion. 


\section{Understanding The Murder: Multiple Approach}

First of all, one must understand the state of mind of the Communists in order to grasp the reasons that led them to go as far as killing someone. The press and the police did not answer this question. The progress of the assassination was known, but for the investigators it was not a priority to understand why they did it. Yet, the reasons that led to the crime are essential to grasp the extremities that were ready to reach certain militants in order to defend their ideals.

\section{A legacy of the battles between the interwar years and the Second World War}

The methods of the Thirties were exacerbated by the memory of the war still present among militants. The context in which the action took place - the return of General de Gaulle after the threat of a military coup, the fear of the establishment of a dictatorship through the referendum, must have revived habits from the Occupation. After all,

"the General had once again become, in the eyes of the Communists, the same adversary they saw as the instrument of fascism and reaction in 1947. Far from being a shield against fascism, he appeared to them in collusion with the rioters of Algiers, that he led to establish his dictatorship."

Louis Richon, a captain during the war and career soldier who was forced to resign because of his membership in the PCF, could havethe impression of relivingsimilar events to the war. He traveled with former resistance fighters to the forest of Bouconne, near Colomiers, to recover weapons (used during the Liberation by the FTP) after the $13^{\text {th }}$ May. His car was accidentally crushed by the Juvaquatre, and one may suppose that Louis Richon had suffered a traumatism, as if he had been convicted of being attacked by the Gestapo, the Militia or the German Army. The witnesses agreed to say that he had radically changed: he never walked without a weapon, like many former party fighters, and was anxious. The same would apply to the passengers of the Frégate, as well as other militants who had arrived earlier in the three vehicles - using molotov cocktails and firearms. The animosity between the two groups and the presence of former resistance fighters among the Gaullists also explains why there was an exchange of gunshots.

\section{"Wash" his honor}

Another reason is the spirit of revenge that prevailed among the Communists. The referendum campaign saw almost daily clashes between Gaullists and Communists, especially around the place Anatole France. Fighting and prosecution were particularly violent and "the men of the far left, fewer than their opponents, regularly have the under". According to François Audigier, it was these repeated fights between Security Service ofeach side that put Richon's men on the alert. Their desire to wash the dishonor suffered by the successive defeats "invites some to equip themselves with molotov cocktails and firearms. And only honor can exist by washing the humiliation suffered", hence the degradation of relations and the tragic turn of the events.

\section{The "hype process" (processus d'emballement)}

The political scientist Philippe Braud brings us another very interesting reading key: the hype process. Any birth or aggravation of a conflict is due to a triggering event that releases tensions that already exists. The desire for revenge of the Communists, as well as the desire to avenge a "martyr" among the Gaullists (after the murder), are only one element among others. The same is true for the antifascism of some and the anti-communism of others. For Braud, it is undeniable that the situation can not degenerate without deep reasons set in time. The opposition between the two movements get back to thirteen years of struggle, or even more within certain resistance groups.Besides, the more a manis accustomed to violence, the more likely heis going to use it. Circumstances are there to make its use more favorable. These are already present with the Algerian war and the events of the $13^{\text {th }}$ May, the rise of General de Gaulle and the divergences between supporters and opponents. The clash between the two vehicles seems to be the trigger event that drove the passengers, frustrated and surprised, to shoot. But they would not have used guns if they had not previously undergo a series of defeats and the fear of seeing a dictatorial regime established. Similarly, the great rejection of the Communists by the population of Toulouse in 1958 was due to the circumstances and to the feeling of treason which the murder of a young23 years old student "revealed".

The work of Michel Maffesoli goes in the direction of Braud and completes his analysis. For the sociologist "nothing escapes the atmosphere of an era, not even those who believe they are totally free from it". The particularly tense context contributes to the action. But even more than the situation, it was the resentments and the hatred that pushed the militants to tear each other apart:

We have the starting point of this labyrinth: constraint, hostility, animosity, a litany that we could pursue endlessly, and which can be sum up by the expression of founding violence. Any social aggregation, it is good to remember, begins with it. The other in itself is violence. The other denies me, and I have to put up with this negation, to compose with it. [...] But the conflict is, in most cases, nothing less than rational, but rather completely affected by affect. This is singularly denied by most 
social observers. This disregard is all the more curious because we know how the production of ideas is most often engendered by polemic, and that political thought in particular tends to be defined pro or against; which could be said to be structured by "sympathy" (or antipathy), not by logic.

\section{The place of emotions}

The Communists felt an immense frustration after the many defeats they were undergoing. Humiliated, they sought reparation through a display of violence. The philosopher Hélène Frappat believes that "the sphere of feelings" plays a crucial role in the action. The group effect is also very important. Sociologists and philosophers are numerous to point this out: Frappat, Maffesoli, Reemtsma, Simmel, Sofsky, Wievorka, etc. For these researchers, the "desire of the collective" of the militants urges them to "experience with others strong emotions". This common action galvanizes men who commit illicit acts more easily. Wolfgang Sofsky also demonstrates this in his treaty of violence. Men feel less guilty when they act in groups. They can be convinced that their actions are less reprehensible or "immoral" because they know they are not the only ones to act. Georges Simmel sums up this "group effect" very well in his sociologie et épistémologie:

The individual feels driven by the quivering "atmosphere" of the mass as if it was an external force, indifferent to his individual being and will. Whereas this mass is made up exclusively of such individuals.

\section{Violence as a manifestation ofweakness?}

Another element that Michel Maffesoli puts forward is the expression of a weakness of a person or a group through violence. The sociologist believes that the "manifestation of the affirmation ofourselves" can be done through violence. It "sends an positive attitude" ("[r]envoie à une attitude affirmative") to those who use it. The Communists were very weakened after the events of May 1958. They were increasingly struggling to make their opposition to De Gaulle's government heard, and they found in physical and symbolic violence an "effective" way of expression. The Gaullists were in a weak position too. While the government was on their side, they were still poorly established in the area. Supported indirectly by the population (which now supported De Gaulle), the supporters of the General remained a minority force in a Radical and socialist fief. They had an interest in showing some boldness to persuade the people of Midi-Pyrénées to vote "yes" to the referendumas soon as possible.For example, the Gaullists, assisted by paratroopers, attacked the headquarters of the PCF Toulouse (streetPargaminières).To remedy this weakness, weapons can offer exceptional capacity for action to militants on both sides. Hélène Frappat explains that these "tools" help to

multiply [their] power. These weapons are not only material objects: their diversity reveals rather the amplitude of the exercise of violence, and its complexity. The weapon is first of all a mean for an end: to attack, to defend ourselves, to threaten, to hold in respect. Whether it is offensive or defensive, it requires skill but also tactical intelligence and cunning.

Thus, the weapon is multifunctional. Although it may serve this purpose, it is not just a tool to hurt. The activist does not necessarily have one to use it (attack or defense). He may want to demonstrate his strength and dissuade his opponent to attack him. In Sofsky's eyes, "it is both materialized violence and symbolic violence. It is a demonstration of power and strength. It gives courage to its possessor and intimidates the adversary". Using weapons makes militants more aggressive. But, as Sofsky points out, what matters most to them is that they can make look more threatening to their opponents. Kafka illustrates this idea with disregard:

Aggressiveness is nothing but powder in the eyes, it is a manoeuver, which is usually only intended to hide from the eyes of the world and in its own eyes the weakness of the person who uses it. We do not really show energy and constancy by undergoing. Only the weak loses patience and becomes rude.

Intimidation does not always work. Between June and September 1958, the Gaullists and the Communists used the same artifices to impress the other. The use of the same methods can deter activists from acting, just as they can "excite" them a little more. When this happens, activists are able to exchange shots "to defend themselves", to try to intimidate or even try to kill their opponents thus commit murder.

\section{The phenomenon of "political strongholds"}

Since the beginning of this article, Idealed only with Maurice Cathala's murder, but one should adopt a broader vision to understand this murder. The area - like the rest of the country - was marked during the referendum campaign by a violence never seen before under the Fourth Republic. 
From 1947 to 1952, the Toulouse area was marked by frequent and unusual violence, but it did not reach such a degree of danger. No murder took place and there was only one "attack" (throwing grenades on Jacques Duclos and his supporters at Auch in 1949).In September 1958, aggressions were sometimes punctuated by attempts to kill with knifes, fire or explosives. The most intense clashes took place in areas where the Gaullists and Communists were the most established. Cities ran by the Communists where full of active gaullist militants. Fightsbroke out between the two groups as well. Solidly settled, they made these places their strongholds. A concept also very important to understand the motivations of these attacks. Considering these areas as their pre-square, they did not tolerate the presence too conspicuous of an opponent. For example, Pamiers, Léran and Saint-Marcel were cities that mostly voted for the PCF.The activities of the supporters of the General were very badly seen by the militants of extreme left. On the contrary, Communists attempts to reactivate their working cells in Mazamet, Labruguière, Millau and Lavelanet provoked the anger of the Gaullists who had slowly settled there. The most violent reaction was in Lavelanet, but other cities witnessed violent fights. These conflicts did not include the Socialists, the Radicals or the Christian Democrats. Their political culture did not predispose them to it. This is why the fights in socialist cities like Muret and SaintGaudens, or Radicals like Cahors and Castelsarrasin, concerned exclusivelygaullists and communists. These confrontations hada twofold objective: to be heard where the opponent had intrenched, and " 'to purify' by a violence considered as legitimate the space soiled by the presence of the other, and thus allow the political geography to return 'to normal'."

To achieve this end, belligerents used two types of violence: (de)localizing violence and autotelic violence. According to the German essayist Reemtsma: "autotelic violence aims the destruction of the integrity of the body". The attacks best fit this description since they seek to destroy buildings and eliminate individuals. However, the aim of the Gaullists and Communists attacks against each otherwas not to "kill to destroy". In reality, the aim of these acts was to drive out an "unwanted" from "its territory". This is why aggressions, injuries, attempted murder and assassinations fall into the first category: violence (de)localising. This oneis therefore necessarily situated in contexts of action aim at something other than the body to which violence is made. [...] In delocalising violence, the body is an obstacle that must disappear. The how does not matter for this attack on the body: it can be pushed away or killed [...]. Delocalizing violence means that a body is not (or is no more) at a certain place [...]. Localized violence is the kind of violence we identify with the violence we encounter in the political space and (mostly) in the field of crime and the fight against it.

Using this definition, one can determine that the violence is clearly (de)localising. The opponents' objective was to repel the "other" of their bastion, and the means used depended on the context, the feelings and the means at their disposal at the time of the confrontation. When gaullist Barthes wanted to blow-out a bomb in Lavelanet, he did not claim that he wanted to kill but "to disrupt" the meeting in order to put an end to it. His method corresponds to the definition of delocalising violence since he sought to expel by all means the Communists and Jacques Duclos from a pro-gaullist site. The murder of Maurice Cathala also responds to a delocalising violence: he was murdered and his "companions" wounded because they militated at the Faculty of Letters of Toulouse, which the PCF perceived as its guarded hunt. Nothing was more insulting and "messy" in the eyes of these militants than to see "the enemy", this threatening "other", encroaching on "his" territory. This was why it seemed necessary for the Communist militants to intervene forcefully to drive out the militants of the Republican Convention.

The Cathala affair did not make Maurice a martyr of the Gaullist cause, his family being identified in 1961 as sympathizing OAS (René and Joseph Cathala strongly defend French Algeria). However, his death deeply shocked in the months following the birth of the Fifth Republic. The Toulousians gathered around the young activist's memory to vote "yes" to the referendum. His death was exploited during the electoral campaign of November by all gaullist candidates of Haute-Garonne. René Cathala, the elder brother of the victim, even managed to win with an anticommunist speech and the memory of his past brother. However, it must be acknowledged that this was not the case for the other departments, which remain insensitive. But as François Audigier indicates in his book, Maurice Cathala's murder marked the minds of the Gaullist militants and contributed to the birth of a political movement that deeply marked the French political life of the next two decades: the SAC (Service d'Action Civique).

\section{References}

English-languageworks

BERENSON E., DUCLERT, V. and PROCHAS, C. (2011). The French Republic:History, Values, Debates.Ithaca and London:CornwellUniversityPress.

JACKSON, W. (2018). De Gaulle. BelknapPress: An Imprint of Harvard UniversityPress.

SHEPARD, T. (2006). The Invention ofDecolonization: The Algerian War and theRemakingof France. Ithaca and London:CornwellUniversityPress. 
THODY, P. (1989). French caesarism. FromNapoleon I to Charles de Gaulle. London: The MacMilanPress.

THOMSON, D. (2006). Democracy in France The Third And FourthRepublics. London:HesperidesPress.

WILLIAMS, P. (1972). Crisis and compromise. Politics in the Forth Republic. London: Longman Group Limited.

French-languageworks

AUDIGIER, F. (2018).Les Prétoriens du général. Gaullisme et violence politique de 1947 à 1959. Rennes:Presses Universitaires de Rennes.

BERSTEIN S., MILZA P. (2009).Histoire de la France au XX ${ }^{\mathrm{e}}$ siècle. II. 1930-1958. Paris: Perrin.

BRAUD P. (2004).Violencespolitiques. Paris: Seuil.

FRAPPAT, H. (2000). Laviolence. Paris, Flammarion.

LERNER H. (1994).De Gaulle et la gauche, Paris:L'Interdisciplinaire.

MAFFESOLI M. (2009).Essais sur la violence. Banale et fondatrice, Paris:CNRS Éditions.

MAFFESOLI M. (2002).La transfiguration du politique. Paris: La Table Ronde.

SOFSKY W. (1998).Traité de la violence.Paris:Gallimard.

REEMSTMA J. P. (2011).Confiance et violence. Essai sur une configuration particulière de la modernité. Paris:Gallimard.

\section{Secondary literature}

Archives of the French Communist Party of Haute-Garonne.

Departmental Archives of Haute-Garonne.

La Dépêche du Midi, Le Figaro, Toulouse Université.

Testimony of Jacques Godfrain, Henri Chataignier, Robert Bergeaud,and Émile Montfort (2015). 